\title{
Municipal Overburden: an Empirical Analysis
}

\author{
Harvey E. Brazer and Therese A. McCarty* \\ Department of Economics, University of Michigan. Ann Arbor, MI 48109, U.S.A.
}

\begin{abstract}
The municipal overburden hypothesis asserts the existence of a causal relationship between high levels of non-school municipal expenditure or tax rates and low levels of school spending. We estimate demand for expenditure on education using a median voter model. The hypothesis is tested by including in the estimating equation several versions of a variable representing municipal overburden. We find no evidence in support of the hypothesis.
\end{abstract}

\section{INTRODUCTION}

THE CONCEPT of "municipal overburden" is a response to concern that large cities cannot adequately finance their schools. It hypothesizes a causal relationship between high levels of nonschool municipal expenditure or high tax rates and low levels of school spending.

The municipal overburden (" $\mathrm{m} / \mathrm{o}$ ") argument has two premises: first, that cities have characteristics such as high population density, aged housing stock, and large concentrations of low. income, unemployed, aged, and minority populations that lead inexorably to high levels of spending for municipal services, and second that there is a fixed fund from which both school and municipal services must be financed. It then claims that spending on education in large cities is relatively low because of unavoidably high levels of spending on municipal services.

The $\mathrm{m} / \mathrm{o}$ hypothesis has been invoked in a number i) challenges to the constitutionality of state systems of school finance, particularly in New Jersey, New York, and Maryland. Our review of the relevant case materials leaves us with the impression that the concept has gained something close to general acceptance in New Jersey, at least considerable respect in New York, and has not been rejected in Maryland. It appears to be established as a legitimate cause of action in suits challenging the constitutionality of state-local systems of financing schools. ${ }^{1}$ Debate in these cases has not had the benefit of adequate empirical evidence or economic analysis. Our objective is to provide these.

\section{THE DEMAND FOR EDUCATION}

\section{The Choice Model}

To test the validity of the $\mathrm{m} / \mathrm{o}$ hypothesis, we need to determine whether or not the requirements of financing municipal services systematically affect the level of education expenditure. To do this. we first need to give a full account of how a community chooses the quantity of education it consumes given its preferences, demographic characteristics, and fiscal circumstances. If $\mathrm{m} / \mathrm{o}$ exists, then we should be able to show that it affects this choice, or in other words, that a measure of $\mathrm{m} / \mathrm{o}$ is an important determinant of the demand for education.

The first difficulty we encounter in estimating the demand for education is in defining our dependent variable, "quantity of education". Education is both a private and a social good, and for the individual it is both a consumption and an investment good. Being so difficult to define, it is, of course, impossible to measure in terms of physical units. We proceed by using "dollars per pupil of expenditure on current account" as our proxy for the quantity of units of educational output. ${ }^{2}$

${ }^{*}$ To whom correspondence should be addressed at: 760 Woodlawn, Jackson, MI 49203, U.S.A. [Manuscript received 70 January 1986; revision accepted for publication 27 April 1986.1 
Next we model the process by which a community chooses the quantity and mix of local public goods that it wishes to consume. We can imagine a spectrum of possible decision-making processes ranging from absolute dictatorship to fully functional representative democracy. We assume that the latter is the appropriate model for our study. In particular, we assume that the median voter, or the voter with median income, age, education, property value owned, and so forth, is the decisive voter. We expect that the quantity of education supplied in each school district will be equal to the median quantity demanded in that district. ${ }^{3}$ The convenience and appeal of this model stem from the fact that it may, as a large group of studies that have used it attest, provide a good approximation to the way things are, and it readily lends itself to empirical estimation. We can estimate the demand equation using readily available data relating to the median voter in each community in our sample.

In our model the median voter is a rational actor whose behavior is designed to maximize his utility given his preference function, the prices he faces, and his income. Not only does he always vote, but his votes are cast in such a way as to be consistent with his utility maximizing behavior over all goods, public and private. As is commonly done, we assume that his demand for public goods can be characterized using a log-linear demand function:

$$
\begin{aligned}
\ln E D= & \ln A+\alpha \ln P_{\mathrm{c}}+\beta \ln P_{\mathrm{m}}+\gamma \ln Y \\
& +\Sigma \delta_{i} \ln Z_{i}+\varepsilon
\end{aligned}
$$

where $P_{\mathrm{c}}$ is the price of education, $P_{\mathrm{m}}$ is the price of other local public goods, $Y$ is median income, $Z$ is a vector of community characteristics that are thought to influence the median voter's decisions, and $\varepsilon$ is an error term with mean of zero. The coefficients in this equation $\left(\alpha, \beta, \gamma, \delta_{\mathrm{i}}\right)$ tell us the sensitivity of expenditure with respect to each of its determinants.

\section{Defining the Determinants of Demand}

Important determinants of demand for any good include price, income, and the prices of other goods. A local public good does not have a price in the sense that a private consumption good has a market price. Instead, we presume that the median voter is cognizant of a "tax price", which is the cost to him in additional tax paid of an increase of one dollar in the level of expenditure per pupil (or per capita in the case of municipal services). Tax price is a function of the median voter's "tax share", or the ratio of the value of his tax base to the community's tax base. It is also affected by the presence of state or federal matching aid, and by deductibility of property taxes for those who itemize deductions on their federal and state income tax returns. The median voter's tax price is entirely independent of his preferences with respect to local public goods and the level of expenditure on those goods.

Ideally we would include measures of the prices of local non-school goods and of private goods. These prices could affect demand for education to whatever extent these goods might be substitutes or complements of education. Unfortunately we have not been able to devise a measure for the price of private goods, or one for local non-school public goods that is sufficiently different from tax price for education.

Our measure of income is comparatively straightforward: median family income $(Y)$.

Lump-sum aid to education affects the median voter by, in effect, extending his budget constraint. ${ }^{4}$ We account for the share of this aid implicitly received by the median voter by multiplying the total amount received under each of the classes of grants by his tax share. ${ }^{5}$ In this way, each class of lump-sum grant may be viewed as an increase in the median voter's income equal to the amount by which the taxes he pays could be reduced without cutting expenditures below the level that would have obtained in the absence of the lump sum grants.

The median voter in each community does not function in a vacuum. Rather, he is subject to a variety of influences that may be grouped under the general head of "community characteristics". They include such factors as the proportion of the population that is over age 64 (AGED), the proportion of residences that are owner occupied (OOC), party preference of the voters (VOTE), the incidence of poverty (POVT), and the proportion of the adult population that has never finished high school (NOHS). We expect that Democrats, traditionally the more liberal spenders, will exert their influence toward higher expenditures for education; but older people, owner occupants, the poor, and those with less than a high school education are all expected to prefer lower outlays for education and to affect, in turn, the preferences of the median voter.

The amounts that are spent for education per pupil are likely also to be influenced by some aspects 
of the schools themselves. We discuss these in the section entitled "Empirical Results".

\section{THE INFLUENCE OF MUNICIPAL OVERBURDEN}

To test for the influence of $\mathrm{m} / \mathrm{o}$ on the demand for education we will successively enter several measures of $\mathrm{m} / \mathrm{o}$ into our demand equation. We have selected measures that are representative of the wide variety of definitions of $\mathrm{m} / \mathrm{o}$ that appear in the literature.

Our first measure of $\mathrm{m} / \mathrm{o}$ is simply the municipal tax rate (MTXRT). This variant reflects the form in which the State of Michigan has recognized $\mathrm{m} / \mathrm{o}$ in supplementing state aid for education. The $\mathrm{m} / \mathrm{o}$ argument holds that a high non-school tax rate reduces the tax rate levied for schools and, therefore, education expenditures. We then test the ratio of municipal to total (municipal plus school) tax rates (TRATIO).

It is sometimes claimed that high municipal expenditures as such constitute a measure of $\mathrm{m} / \mathrm{o}$. But expenditures do not in themselves burden taxpayers or voters. They are financed out of state and federal aid and non-tax revenues such as user charges, fees, fines, and licenses, as well as taxes, and it is most unlikely that any of these other than taxes can be seen as impinging on school financing .ny more than does any other voluntarily undertaken disposition of income. It seems to us that the measure of expenditures for municipal purposes that is relevant in this context is tax-financed expenditures per capita (TFEXP). ${ }^{7}$

A variant of this theme that may be appropriate for testing the $\mathrm{m} / \mathrm{o}$ hypothesis is the ratio of taxfinanced expenditures to personal income (TFYRTO). This variable provides a measure of the relative burden imposed by local taxes for municipal purposes.

The measures of $\mathrm{m} / \mathrm{o}$ used in these first four tests are likely to be determined by many of the same influences that determine educational expenditures. To account for this, we conduct these tests using two-stage least squares (2SI S) rather than ordinary least squares (OLS). ${ }^{8}$

Even when expenditures are reduced to the level tinanced by local taxation they continue to reflect the influences of income, price, and tastes or preferences. They reflect only in part, perhaps only in small part, circumstances giving rise to differences in "need". By "need" we mean a level of expenditures that is independent of income (including federal and state aid), price, and preferences; it is a function simply of the other characteristics of the community that govern demand for municipal services, such as population density, the incidence of poverty, aged housing and people, and so forth. To estimate "need" (NEED) we first estimate a demand equation for municipal operating expenditures," then using the sample means for price, income, aid, and our proxies for preferences, we calculate NEED for each community.

The last of our $\mathrm{m} / \mathrm{o}$ tests involves substituting income less "need" for median family income, to give us a variable that may be defined as a form of disposable income, "disposable" in the sense that municipal "needs" have been deducted. If the m/o argument is to gain support through this approach the equation containing YNEED in lieu of $Y$ (median family income) should enable us to better explain the determinants of expenditure. ${ }^{11}$

\section{EMPIRICAL RESULTS}

We have estimated our expenditure demand equations by performing regression analysis on samples of school districts from three states, Connecticut, New Jersey, and Virginia. ${ }^{11}$ This technique reveals the degree to which each variable can be said to influence demand

The results of our analysis, which are presented in Table 1 , tend to be supportive of the median voter model. The elasticities generally have the expected sign and are within the range suggested by earlier studies (e.g. Lovell, 1978) and theoretical considerations. ${ }^{12}$ The overall fit of the regressions is good, as is indicated by the corrected values of $R^{2}$ that range from 0.55 for New Jersey to 0.77 for Connecticut. ${ }^{13}$

I he elasticity of tax price is consistently negative. Its value of -0.14 in New Jersey, while clearly statistically significant, implies a high degree of insensitivity of demand to differences in price. ${ }^{14}$ This is much less true in Connecticut and Virginia, where the coefficients are -0.32 and -0.28 .

The level of family income plays a major role in the demand for education. The elasticities of demand with respect to income are 0.62 (Connecticut), 0.32 (New Jersey), and 0.43 (Virginia). This means that an increase of $\$ 1$ in income in each of the three states would be associated with an 
Table 1. Demand for education expenditures: parameter estimates, 1981-1982

\begin{tabular}{|c|c|c|c|}
\hline Predictor variables & Connecticut & New Jersey & Virginia \\
\hline CONSTANT & $4.4 \dagger$ & $\begin{array}{l}5.4^{*} \\
(0.65)\end{array}$ & 2.4 \\
\hline TAXPRICE & $\begin{array}{c}-0.32^{*} \\
(0.078)\end{array}$ & $\begin{array}{c}-0.14^{*} \\
(0.038)\end{array}$ & $\begin{array}{c}-0.28^{*} \\
(0.096)\end{array}$ \\
\hline MEDFMY & $\begin{array}{r}0.62^{*} \\
(0.13)\end{array}$ & $\begin{array}{c}0.32^{*} \\
(0.060)\end{array}$ & $\begin{array}{c}0.48^{*} \\
(0.16)\end{array}$ \\
\hline DASICAID & $\begin{array}{c}-0.0016 \\
(0.0037)\end{array}$ & $\begin{array}{c}0.013 \\
(0.015)\end{array}$ & $\begin{array}{c}-0.14 \\
(0.076)\end{array}$ \\
\hline STCATAID & $\begin{array}{c}0.064 \\
(0.034)\end{array}$ & $\begin{array}{c}0.0025 \\
(0.0097)\end{array}$ & $\begin{array}{c}0.26^{*} \\
(0.085)\end{array}$ \\
\hline FEDAID & $\begin{array}{r}-0.0089 \\
(0.034)\end{array}$ & $\begin{array}{c}0.032 * \\
(0.0076)\end{array}$ & $\begin{array}{c}0.14^{*} \\
(0.036)\end{array}$ \\
\hline AGED & $\begin{array}{c}0.16^{*} \\
(0.059)\end{array}$ & $\begin{array}{c}0.090^{*} \\
(0.025)\end{array}$ & $\begin{array}{r}-0.0065 \\
(0.060)\end{array}$ \\
\hline SECPUP & $\begin{array}{r}-0.092 \\
(0.13)\end{array}$ & $\begin{array}{c}0.18^{*} \\
(0.050)\end{array}$ & $\begin{array}{c}0.049 \\
(0.15)\end{array}$ \\
\hline NOIIS & $\begin{array}{l}-0.097 \dagger \\
(0.040)\end{array}$ & $\begin{array}{r}0.047 \dagger \\
(0.021)\end{array}$ & $\begin{array}{c}0.046 \\
(0.066)\end{array}$ \\
\hline VOTE & $\begin{array}{c}0.18^{*} \\
(0.064)\end{array}$ & $\begin{array}{r}0.068+ \\
(0.032)\end{array}$ & $\begin{array}{c}0.068 \\
(0.063)\end{array}$ \\
\hline PUPFM & $\begin{array}{c}0.12 \\
(0.12)\end{array}$ & $\begin{array}{c}0.076 \\
(0.050)\end{array}$ & $\begin{array}{r}-0.27 \dagger \\
(0.12)\end{array}$ \\
\hline ENRGR & $\begin{array}{r}-0.57^{*} \\
(0.19)\end{array}$ & $\begin{array}{r}-0.28^{*} \\
(0.10)\end{array}$ & $\begin{array}{c}-0.26 \\
(0.17)\end{array}$ \\
\hline OOC & $\begin{array}{r}-0.026^{*} \\
(0.080)\end{array}$ & $\begin{array}{c}-0.12^{*} \\
(0.028)\end{array}$ & $\begin{array}{r}-0.35^{*} \\
(0.11)\end{array}$ \\
\hline PRIV & $\begin{array}{c}0.015 \\
(0.023)\end{array}$ & $\begin{array}{r}0.029 \dagger \\
(0.013)\end{array}$ & $\begin{array}{r}-0.014 \\
(0.013)\end{array}$ \\
\hline POVT & $\begin{array}{c}0.00013 \\
(0.028)\end{array}$ & $\begin{array}{c}-0.013 \\
(0.015)\end{array}$ & $\begin{array}{r}-0.010 \\
(0.064)\end{array}$ \\
\hline PUP & $\begin{array}{c}-0.91^{*} \\
(0.24)\end{array}$ & $\begin{array}{c}-0.18 \dagger \\
(0.085)\end{array}$ & $\begin{array}{c}-0.21 \\
(0.15)\end{array}$ \\
\hline PUPSQ & $\begin{array}{r}0.057^{*} \\
(0.015)\end{array}$ & $\begin{array}{c}0.011 \dagger \\
(0.0055)\end{array}$ & $\begin{array}{c}0.012 \\
(0.0088)\end{array}$ \\
\hline DEPDIST & & $\begin{array}{c}-0.036 \\
(0.028)\end{array}$ & \\
\hline MEMB & & $\begin{array}{c}-0.13^{*} \\
(0.023)\end{array}$ & \\
\hline NONRS & $\begin{array}{c}-0.0077 \\
(0.0060)\end{array}$ & $\begin{array}{c}-0.0017 \\
(0.0041)\end{array}$ & \\
\hline SENT & $\begin{array}{c}-0.033^{*} \\
(0.011)\end{array}$ & $\begin{array}{c}-0.0080 \\
(0.0042)\end{array}$ & \\
\hline $\bar{R}^{2}$ & 0.77 & 0.55 & 0.73 \\
\hline$n$ & 99 & 380 & 121 \\
\hline SEE & 0.080 & 0.12 & 0.10 \\
\hline
\end{tabular}

Notes: (1) Standard errors appear in parentheses. (2) All regression equations are in log-linear form. (3) Coefficients marked with a dagger $(\dagger)$ are significant at the $5 \%$ level, and those marked with an asterisk $\left({ }^{*}\right)$ are significant at the $1 \%$ level.

increase in per pupil expenditures of $\$ 0.06$ in Connecticut, $\$ 0.04$ in New Jersey, and $\$ 0.06$ in Virginia. ${ }^{15}$

Recall that, in our model, lump-sum federal and state aid for education is equivalent to an increase in income for the median voter equal to total aid times his tax share. The elasticity with respect to basic aid is not significantly different from zero in any of our states. We expect categorical or earmarked aid to have a substantially larger effect on expenditure 
than unrestricted aid as it often supports mandated programs on which districts would otherwise spend nothing. Our results support this theory, although somewhat tentatively, in that some of the relevant coefficients are not quite significant at the $5 \%$ level.

Of the community characteristics that we have included among our explanatory variables, the percentage of owner-occupied housing (OCC) stands out as being the most consistently significant across states, suggesting that owner-occupiers prefer to spend less on public services than renters do, other things equal. The coefficients of our other measures of voter preferences, the proportion of the idult population that did not attend high school (NOHS) and the proportion of Democratic voters (VOTE), are consistently negative and positive respectively and significant in Connecticut and New lersey. Neither is significant in Virginia.

Our results do not support the view that the presence of a large elderly population (AGED) tends to depress spending on education. Similarly, poverty (POVT) does not seem to affect spending. ${ }^{\text {in }}$

We can draw some general conclusions about the uffects of school characteristics, although these tindings are not always supported by statistically significant cocfficients in all three states. Higher rates of enrollment growth (ENRGR) generally are associated with lower spending: The effect of district size (PUP and PUPSQ) is non-linear: per pupil expenditures fall and then rise as enrollment grows.
The presence of non-resident pupils (NONRS), the proportion of pupils sent to school in other districts (SENT), the proportion of pupils in high school (SECPUP), the fraction of pupils who are enrolled in non-public schools (PRIV), and the number of pupils per family (PUPFM) do not appear to have a systematic influence on expenditure. Finally, in New Jersey, membership in a regional high school district (MEMB) lowers spending, while our test of the effect of a district's status as dependent (part of a municipal government) or independent (DEPDIST) is inconclusive.

In spite of our finding that several variables, most notably price and income, explain a large part of the variance in expenditure in each of our states, ${ }^{17}$ unexplained variance ranging from $40 \%$ in New Jersey to $20 \%$ in Connecticut remains. We are left, then, knowing that factors we have not considered also influence expenditure on education. We now turn to our tests of the influence of $\mathrm{m} / \mathrm{o}$ to see if it might be one of these.

\section{Results of the Municipal Overburden Tests}

We have tested each of the six versions of the m/o hypothesis outlined above by including it in our estimation equation for education cxpenditure. Results of these tests are presented in Table 2. (Tables reporting the coefficients for all variables in these six regressions are available from the authors upon request.)

Table 2. Tests for municipal overburden: parameter estimates, 1981-1982

\begin{tabular}{|c|c|c|c|c|c|c|}
\hline \multirow[b]{2}{*}{$\begin{array}{c}\text { Vunicipal overburden } \\
\text { test variables }\end{array}$} & \multicolumn{2}{|c|}{ Connecticut } & \multicolumn{2}{|c|}{ New Jersey } & \multicolumn{2}{|c|}{ Virginia } \\
\hline & $\begin{array}{l}\text { Parameter } \\
\text { estimate }\end{array}$ & $\bar{R}^{2}$ & $\begin{array}{l}\text { Parameter } \\
\text { estimate }\end{array}$ & $\bar{R}^{2}$ & $\begin{array}{l}\text { Parameter } \\
\text { estimate }\end{array}$ & $\bar{R}^{2}$ \\
\hline \multirow[t]{2}{*}{ MTXRT } & -0.082 & & 0.096 & & 0.12 & \\
\hline & $(0.073)$ & 0.74 & $(0.054)$ & 0.53 & $(0.10)$ & 0.69 \\
\hline \multirow[t]{2}{*}{ TRATIO } & -0.12 & & 0.22 & & 0.19 & \\
\hline & $(0.15)$ & 0.74 & $(0.13)$ & 0.47 & $(0.16)$ & 0.55 \\
\hline \multirow[t]{2}{*}{ TFEXP } & -0.24 & & -0.12 & & -0.23 & \\
\hline & $(0.27)$ & 0.49 & $(0.095)$ & 0.46 & $(0.075)$ & 0.70 \\
\hline \multirow[t]{2}{*}{ TFYRATIO } & -0.16 & & -0.11 & & 0.036 & \\
\hline & $(0.18)$ & 0.62 & $(0.10)$ & 0.47 & $(0.073)$ & 0.74 \\
\hline \multirow[t]{2}{*}{ NEED } & -0.21 & & 0.17 & & 0.066 & \\
\hline & $(0.13)$ & 0.78 & $(0.13)$ & 0.55 & $(0.033)$ & 0.73 \\
\hline \multirow[t]{2}{*}{ YNEED } & $0.58^{*}$ & & $0.25^{*}$ & & $0.45^{*}$ & \\
\hline & $(0.12)$ & 0.77 & $(0.054)$ & 0.54 & $(0.15)$ & 0.73 \\
\hline
\end{tabular}

Noies: (1) Standard errors appear in parentheses. (2) All regression equations are in log-linear form. (3) Coefficients marked with a dagger $(\dagger)$ are significant at the $5 \%$ level, and those marked with an asterisk $\left(^{*}\right)$ are significant at the $1 \%$ level. 
In the first five tests, if the coefficient for our $\mathrm{m} / \mathrm{o}$ test variable were negative and statistically significant, we would have some evidence that $\mathrm{m} / \mathrm{o}$ influences expenditure on education. However, the only coefficient that is statistically significant is positive rather than negative. Those that are negative are not statistically distinguishable from zero. In the sixth test, in which income minus "need" is substituted for median family income, we find that this measure of "disposable income" does not explain expenditure better than income does. If it did, we would expect our measure of the extent to which variance in expenditure is explained, corrected $R^{2}$, to rise. Thus none of our tests is able to support the $\mathrm{m} / \mathrm{o}$ hypothesis.

\section{ON THE ECONOMICS OF MUNICIPAL OVERBURDEN}

Our efforts to find evidence supportive of the $\mathrm{m} / \mathrm{o}$ hypothesis come up quite empty. A hypothesis that seems quite reasonable on its face simply fails our empirical tests. There are several plausible explanations for this finding.

First, the tax cost of municipal non-school services amounts only to an average of $2.8 \%$ of personal income in Connecticut, $3 \%$ in New Jersey, and $2 \%$ in Virginia. Furthermore, much of these proportions of income may be borne or may be perceived as being borne by non-residents who own or are customers of a community's industrial and commercial properties. Even large variance, between, say, 1 and $6 \%$ of income, is unlikely to appreciably influence the demand for any one category of goods, including education.

To see why this must be so, suppose that local financing of non-school services reduces disposable income by the amount spent, ${ }^{18}$ and that the income elasticity of demand for education is $1 .^{19}$ Then, if $3 \%$ of income is spent for municipal services, expenditures for schools would be $3 \%$ lower than they would have been in the absence of expenditures for those services. Alternatively, if one municipality spends $1 \%$ of income on non-school services while another spends $6 \%$, a range unlikely to be seen often, the effect on school expenditures would be to produce a difference between the two districts, other things equal, of only $5 \%$, hardly enough to warrant the kinds of conclusions judges have drawn in Maryland, New Jersey, and New York.

A second relevant observation is the fact that demand for municipal services and demand for education are influenced by much the same factors, so that where the demand for the one is high the demand for the other is also likely to be high. In fact, we find that the simple correlation coefficients between municipal and education expenditure are positive: 0.60 for Connecticut, 0.26 for New Jersey, and 0.70 for Virginia.

It is also worth noting that the presence of relatively high municipal (non-school) expenditures in large cities does not necessarily constitute evidence that those expenditures are burdensome. Some urban public services may be alternatives to private purchase in a rural area of garbage disposal, trash collection, sewage removal, or fire and police protection. A person who pays much more for police and fire protection because she chooses to live in close proximity to her neighbors in the city is not necessarily worse off, or less willing or able to pay school taxes, than the one who pays for an equal probability of being subject to crime or fire in the costs of commuting to the city from her sparsely populated rural residence (Brazer et al., 1971).

Furthermore, municipal expenditure in large cities is offset by intergovernmental grants and user charges to a larger extent than in other communities. The level of tax-financed expenditure in large cities is not nearly as high relative to that of other communities as is the level of total municipal expenditure. This makes the finding that municipal expenditure is not more "burdensome" in cities even less surprising.

It is our view, based on our findings, that the $\mathrm{m} / \mathrm{o}$ hypothesis is not a valid or reasonable basis on which to rest the claim for special assistance for urban school districts. If stressed districts are to be helped, aid should be based on factors that are directly indicative of the underlying factors that give rise to fiscal stress. These may include incidence of children living in poverty, of children whose command of the English language is below acceptable standards, level of family income, tax base per pupil, and other relevant indices of costs and fiscal capacity. We find that $\mathrm{m} / \mathrm{o}$ is simply not a helpful concept in fact, however much it may appeal to "common sense." 
Acknowledgements - The authors are indebted to several colleagues for a number of important insights. We are particularly grateful to T. C. Bergstrom, Roger Gordon,
Saul H. Hymans and Judith Roberts. The study was made possible by a grant from the National Institute for Education, No. NIE/G-83-0052.

\section{NOTES}

1. M/o has only been explicitly recognized by the legislature of one state, Michigan, where districts whose non-school tax rate exceeds $125 \%$ of the statewide average receive supplementary school aid. Several other states adjust state aid for high population density, low income, or large numbers of children living in poverty. These adjustments may in some cases reflect concern about $\mathrm{m} / \mathrm{o}$.

2. This approach requires a rather bold assumption, that a one dollar purchase of inputs to the educational process produces equal quantities of output everywhere. Also, in dividing expenditure by enrollment, we assume that the number of pupils is not influenced by expenditure.

3. For a discussion of the median voter model see Bergstrom and Goodman (1973).

4. Minimum aid in Connecticut and New Jersey, and most general aid in Virginia, as well as federal and state categorical aid are of lump sum variety. Basic aid is matched in New Jersey, but it is the previous year's expenditures that are subject to matching. Thus we believe that state aid does not directly influence the current year's perceived tax price of education, and we therefore treat it as lump sum aid.

5. The classes of grants as we have defined them are general or basic state aid (BASICAID), categorical state aid (STCATAID), and federal aid (FEDAID).

6. We do not include this because it seems to us to be a convincing articulation of the $\mathrm{m} / \mathrm{o}$ concept, but rather because this version of the $\mathrm{m} / \mathrm{o}$ hypothesis has been so often stated before the courts in recent litigation. See, for example, the opinion of Judge Ross in Somerset County Board of Education et al. v. David W. Hornbeck et al., Circuit Court of Baltimore, quoted in 295 Md. 597 (1983).

7. Obviously TFEXP is identical to tax receipts. Thus an alternative way of viewing this variation of $\mathrm{m} / \mathrm{o}$ is that it is the municipal tax level rather than the tax rate that impinges on expenditures for schools.

8. To create instruments we have used variables that affect demand for municipal services but not demand for school expenditures: density, fraction of housing stock that is old, percentage of property value that is industrial, percentage of the population that is black, and the unemployment rate. We used a slightly different set of variables in each state.

9. The Appendix outlines the procedure we use to estimate demand for municipal expenditure.

10. It should be noted that NEED is expressed as "need" per capita, whereas YNEED is median family income less "need" per family.

11. Our selection of these states was dictated in part by the fact that in these states school districts and municipalities are largely coterminous, and by a desire to achieve some degree of regional diversity.

12. Because our demand equations have a log-linear form, the estimated coefficients tell us the percentage change in expenditure given a $1 \%$ change in the relevant variable, or the elasticity of expenditure with respect to that variable.

13. This measure tells us the percentage of variance in expenditure across communities that our variables explain when taken together.

14. If a coefficient is "statistically significant" at the $5(1) \%$ level, then we can be $95(99) \%$ certain that it is different from zero.

15. We compute the absolute change in expenditure given a one unit change in income by multiplying the income elasticity by the ratio of the means of expenditure and income.

16. The poverty coefficient is measuring the effect of poverty when other factors, including median family income, are held constant.

17. Tax price and median family income by themselves account for $42 \%$ of total variance in demand for education in Connecticut, $19 \%$ in New Jersey, and $32 \%$ in Virginia. Community characteristics raise these proportions of variance explained by 27,23 and 33 points, respectively, in the three states.

18. This is, of course an extreme and unrealistic assumption, one that concedes everything to those who argue the "inexorability" of municipal expenditures.

19. This is higher than most estimates of the income elasticity of demand we have seen.

20. As in the case of the equation for the demand for education, we cannot include both $P_{\mathrm{e}}$ and $P_{\mathrm{m}}$ because they are so close in value and virtually identical in New Jersey and Virginia, where very little of aid for schools is matching aid. 
21. Some studies have found the employment/resident ratio to be an important determinant of municipal expenditures in some states. We have tested this hypothesis using the ratio of the sum of manufacturing, retail trade, and service employees to resident population, and have not found a significant relationship in our sample. We also considered including the following variables: the percentage of the population that is black and Puerto Rican, the percentage of the population over 25 that has no high school education, and the rate of population growth. We found that our results do not differ in any important way when these are included. We have no compelling theoretical reason to include them, so we have not.

22. We include expenditures of the overlying county in New Jersey, allocating them on a per capita basis. However, in New Jersey, we were unable to compute TFEXP properly, so we used current expenditure less user charges (EXPNOCHG) in its place. In Connecticut the counties are of no fiscal consequence and are ignored, while in Virginia outside of the cities the county is the relevant local government, and the cities are independent of the counties.

\section{REFERENCES}

Bergstrom, T. and Goodman, R. (1973) Private demand for public goods. Am. Econ. Rev. 63 , 280-296.

Brazer, H. et al. (1971) Fiscal Needs and Resources. A Report to the New York State Commission on the Quality, Cost, and Financing of Elementary and Secondary Education.

LOVELl, M. (1978) Spending for education: the exercise of public choice. Rev. Econ. Statist. 60, $487-495$.

\section{APPENDIX. DEMAND FOR MUNICIPAL SERVICES}

Our main concerns in estimating the demand for municipal services are to obtain equations that will permit us to estimate "need" and to test the accuracy of one of the premises of the m/o argument: the hypothesis that such conditions as a high incidence of poverty, unemployment, older housing, and aged people, together with high population density give rise inexorably to high per capita expenditures for non-school local public goods.

Using the same methodological approach as we outlined in the case of the demand for education, we can specify the demand equation for municipal non-school expenditures in log-linear form as

$$
\ln E_{\mathrm{m}}=\ln B+\zeta \ln P_{\mathrm{m}}+\eta \ln P_{\mathrm{e}}+\kappa \ln Y+2 \lambda_{\mathrm{i}} \ln Z_{\mathrm{i}}+\mu
$$

where $P_{\mathrm{m}}$ is the price of municipal services, $P_{\mathrm{e}}$ is the price of education, ${ }^{20} Y$ is median family income, and $Z$ is a vector of other variables, including state and federal aid (ASMNT and AFMNT, respectively) and relevant community characteristics, in particular DENS, AGED, OLDHSE, UNEMRT, and POVT.

Our list of explanatory variables also includes dummy variables identifying communities that are central cities (CENCITY) and those that are located outside a Standard Metropolitan Statistical Area (NSMSA), as well as population size (POP), the proportion of residences that are owner occupied $(\mathrm{OOC})$, and the proportion of votes cast for Democratic Party candidates (VOTE). ${ }^{21}$

We estimate demand for municipal expenditure using two different forms of the dependent variable: total expenditure (CURREXP) and tax-financed expenditure (TFEXP). We use the latter in estimating NEED ${ }^{22}$ Results are presented in Table $A$.

The results are gencrally quite consistent with those of other studies and with standard economic theory. Our equations "explain" between 60 and almost $90 \%$ of variance without much belp from factors that are often said to raise expenditure inexorably such as population density, the rate of unemployment, high incidence of poverty and aged people, large proportions of aging housing, or being a central city. As in the case of education, the most important of the determinants of the expenditures of cities for local public goods are tax price, income, aid, and some proxies for voter preferences. 
Table A. Demand for municipal expenditures: Parameter estimates, 1981-1982

\begin{tabular}{|c|c|c|c|c|c|c|}
\hline \multirow{2}{*}{$\begin{array}{l}\text { Predictor } \\
\text { variables }\end{array}$} & \multicolumn{2}{|c|}{ Connecticut } & \multicolumn{2}{|c|}{ New Jersey } & \multicolumn{2}{|c|}{ Virginia } \\
\hline & CURREXP & TFEXP & CURREXP & EXPNOCHG & CURREXP & TFEXP \\
\hline \multirow[t]{2}{*}{ CONSTANT } & $-5.8^{*}$ & $-6.6+$ & $2.2^{*}$ & $2.3^{*}$ & -3.3 & $-12.5+$ \\
\hline & $(1.6)$ & $(2.7)$ & $(0.73)$ & $(0.73)$ & $(2.2)$ & $(5.6)$ \\
\hline \multirow[t]{2}{*}{ MEDFMY } & $1.0^{*}$ & $1.2^{*}$ & $0.26^{*}$ & $0.22^{*}$ & $0.59 \dagger$ & $1.3+$ \\
\hline & $(0.19)$ & $(0.32)$ & $(0.086)$ & $(0.085)$ & $(0.26)$ & $(0.68)$ \\
\hline \multirow[t]{2}{*}{ TAXPRICE } & $-0.49^{*}$ & -0.30 & $-0.56^{*}$ & $-0.57^{*}$ & $-0.71^{*}$ & $-0.53 t$ \\
\hline & $(0.099)$ & $(0.17)$ & $(0.041)$ & $(0.041)$ & $(0.092)$ & $(0.23)$ \\
\hline \multirow[t]{2}{*}{ DENS } & 0.050 & 0.13 & $0.022^{*}$ & 0.014 & $0.13^{*}$ & $0.28^{*}$ \\
\hline & $(0.040)$ & $(0.066)$ & $(0.0087)$ & $(0.0087)$ & $(0.023)$ & $(0.059)$ \\
\hline \multirow[t]{2}{*}{ POP } & $0.12 \dagger$ & 0.096 & 0.022 & $0.028+$ & 0.023 & $0.18^{*}$ \\
\hline & $(0.045)$ & $(0.076)$ & $(0.014)$ & $(0.014)$ & $(0.025)$ & $(0.063)$ \\
\hline \multirow[t]{2}{*}{$\mathrm{OOC}$} & $-0.55^{*}$ & $-0.72^{*}$ & $-0.23^{*}$ & $-0.21^{*}$ & -0.15 & 0.037 \\
\hline & $(0.15)$ & $(0.25)$ & $(0.043)$ & $(0.043)$ & $(0.17)$ & $(0.44)$ \\
\hline \multirow[t]{2}{*}{$\triangle G E D$} & 0.16 & 0.26 & $0.064 \dagger$ & 0.048 & 0.12 & -0.083 \\
\hline & $(0.090)$ & $(0.15)$ & $(0.030)$ & $(0.030)$ & $(0.098)$ & $(0.025)$ \\
\hline \multirow[t]{2}{*}{ OLDHSE } & 0.065 & 0.059 & 0.012 & 0.020 & -0.082 & -0.34 \\
\hline & $(0.059)$ & $(0.099)$ & $(0.016)$ & $(0.016)$ & $(0.050)$ & $(0.13)$ \\
\hline \multirow[t]{2}{*}{ UNEMRT } & $(0.074)$ & -0.034 & $0.14^{*}$ & $0.14^{*}$ & 0.12 & 0.10 \\
\hline & $(0.084)$ & $(0.14)$ & $(0.036)$ & $(0.036)$ & $(0.073)$ & $(0.19)$ \\
\hline \multirow[t]{2}{*}{ POVT } & 0.058 & 0.044 & 0.022 & 0.020 & 0.024 & 0.0054 \\
\hline & $(0.060)$ & $(0.10)$ & $(0.022)$ & $(0.022)$ & $(0.10)$ & $(0.26)$ \\
\hline \multirow[t]{2}{*}{ FEDAID } & $0.15^{*}$ & $0.11 \dagger$ & 0.032 & $0.048+$ & $0.12^{*}$ & $-0.45^{*}$ \\
\hline & $(0.029)$ & $(0.048)$ & $(0.024)$ & $(0.024)$ & $(0.035)$ & $(0.090)$ \\
\hline \multirow[t]{2}{*}{ STAID } & 0.014 & $-0.42^{*}$ & $0.30^{*}$ & $0.31^{*}$ & $0.49^{*}$ & $0.68^{*}$ \\
\hline & $(0.039)$ & $(0.066)$ & $(0.025)$ & $(0.025)$ & $(0.094)$ & $(0.24)$ \\
\hline \multirow[t]{2}{*}{ VOTE } & $0.36^{*}$ & $0.47 \dagger$ & -0.051 & -0.051 & 0.034 & 0.46 \\
\hline & $(0.13)$ & $(0.22)$ & $(0.048)$ & $(0.048)$ & $(0.11)$ & $(0.28)$ \\
\hline \multirow[t]{2}{*}{ CENCITY } & 0.031 & 0.22 & $0.18^{*}$ & $0.17^{*}$ & 0.12 & 0.18 \\
\hline & $(0.086)$ & $(0.14)$ & $(0.052)$ & $(0.052)$ & $(0.083)$ & $(0.21)$ \\
\hline \multirow[t]{2}{*}{ NSMSA } & -0.053 & 0.051 & -0.016 & -0.0095 & $0.12 \dagger$ & $0.31+$ \\
\hline & $(0.063)$ & $(0.10)$ & $(0.035)$ & $(0.035)$ & $(0.052)$ & $(0.13)$ \\
\hline$R^{2}$ & 0.80 & 0.65 & 0.61 & 0.61 & 0.87 & 0.65 \\
\hline n & 99 & 99 & 380 & 380 & 121 & 121 \\
\hline SEE & 0.17 & 0.29 & 0.17 & 0.17 & 0.19 & 0.49 \\
\hline
\end{tabular}

Notes: (1) Standard errors appear in parentheses. (2) All regression equations are in log-linear form. (3) Coefficients marked with a dagger $(\dagger)$ are significant at the $5 \%$ level, and those marked with an asterisk $(*)$ are significant at the $1 \%$ level. (4) We were unable to compute TFEXP properly for New Jersey, so we used EXPNOCG in its place. 